УДК 378.047

DOI https://doi.org/10.52726/as.pedagogy/2021.3.1.26

\author{
ЯН МЕН'ї \\ аспірант кафедри соиіальної педагогіки, \\ Національний педагогічний університет імені М. П. Драгоманова, \\ м. Київ, Украӥна -Китай \\ Електронна nошта: sivkivskay@gmail.com,714862806@qq.com \\ https://orcid.org/0000-0001-8163-5531
}

\title{
ЗНАЧЕННЯ КОМУНІКАТИВНОЇ КУЛЬТУРИ ЗДОБУВАЧІВ ВИЩОЇ ОСВІТИ ДЛЯ ЇХ ПРОФЕСІЙНОГО РОЗВИТКУ
}

\begin{abstract}
У статті проаналізовано проблему комунікативної культури як соціально-психологічного складника у структурі особистості, що дозволяє особистості розвиватись у гармонії із загальнолюдською культурою та набувати соціальну стійкість. Визначено, що в іiї основі лежать моральні цінності, знання про види і форми спілкування, якості, потрібні для повноцінного спілкування. Метою дослідження є теоретичне обгрунтування значення комунікативної культури здобувачів вищої освіти для їх професійного становлення під час навчання. Подано теоретичний аналіз вітчизняної і зарубіжної науково-методичної літератури. Проаналізовано різні авторські погляди на поняття «комунікативна культура». Узагальнено культуроутворюючі компоненти комунікативної культури: емоційна культура або культура почуттів, культура мислення та мовна культура.

Установлено, що комунікативна культура передбачає наявність комунікативного ідеалу, системи комунікативних норм і правил, власних комунікативних здібностей і вмінь. Визначено, що комунікативна культура забезпечує готовність особистості до життєвого і професійного самовизначення та є умовою успішного професійного розвитку майбутнього фахівця. Виявлено професійні компоненти комунікативної культури фахівця. Доведено, що засобом та умовою комунікативної культури є комунікативна діяльність, тому під час професійної підготовки здобувачів вищої освіти висуваються вимоги, яким має відповідати комунікативна діяльність майбутнього фахівця. Для фахівця як суб'єкта професійної діяльності способом пізнання і перетворення світу є професійна культура, а способом перетворення себе - комунікативна культура. У цьому випадку комунікативна культура є сукупністю спеціальних комунікативних знань, навичок і вмінь, за допомогою яких людина уникає психологічних труднощів і прогнозує результативність міжособистісної та ділової професійної взаємодії.
\end{abstract}

Ключові слова: комунікація, комунікативна діяльність, комунікативна культура, здобувач вищої освіти.

Вступ. У сучасному суспільстві комунікація має всеосяжний, унікальний за інтенсивністю характер, інтегруючи весь соціум в єдину комунікативну систему, і стає умовою усвідомлення свободи, індивідуальності, етичної та моральної відповідальності. Без визначення загальних закономірностей і сучасних особливостей розвитку комунікативної культури суспільства та особистості розвиток професійної освіти неможливий. Ефективність професійної діяльності сучасного спеціаліста залежить від багатьох факторів. Серед них особливе місце посідає успішна комунікативна діяльність як основа соціальних взаємин, співпраці, досягнення взаєморозуміння і втілення цілей професійної діяльності, як спосіб самовдосконалення і забезпечення особистісного розвитку. Аналіз проблем формування комунікативної культури студента представлено у працях Н. Бабича, Н. Волкової, О. Гаврилюка, Д. Годлевської, А. Капської, Н. Кузьміної, Н. Литвиненка,
Н. Місника, Н. Митрової, Л. Руденка, В. Соколової, В. Тернопільської та інших.

Розглядаючи комунікацію через діяльнісний підхід, варто зазначити, що комунікативну діяльність визначають як взаємодію живих істот між собою, їх цілеспрямовані й активні дії із явищами і предметами об'єктивного світу на основі обміну інформацією. Ми погоджуємося 3 думкою Н. Митрової, яка зазначає, що комунікативна діяльність - це «форма людської активності, спрямована на здійснення соціальної взаємодії людей, яка полягає у передачі соціально значущої інформації, обміні інформацією, організації взаємодії суб'єктів комунікації, сприйняття один одного партнерами і встановлення на цій основі взаєморозуміння» [Митрова : 148].

У системі культур особливе місце посідає комунікативна культура, яка $є$ атрибутом будьякого виду діяльності, що інтегрує всі види культури: професійну, духовну, пізнавальну, 
родинно-побутову, художню, етичну, інтелектуальну, релігійну, екологічну, політичну тощо.

Виклад основного матеріалу. Усвідомлення статусу комунікативної культури як базового компонента професійної підготовки здобувача вищої освіти відбулося у сучасний період; це положення грунтується на загальних уявленнях про професійну культуру, запропонованих М. Капушевою. Роль і місце комунікативної культури у структурі професійної культури фахівця оцінюється по-різному. Найбільш розробленою нині є особистісно орієнтована концепція, що характеризується пріоритетом компонента культури у поєднанні з комунікативною культурою. Відповідно до цієї концепції співвіднесення поняття «комунікативна культура» із загальною та професійною культурами виглядає так: загальна і професійна культура представляються родовими поняттями відносно комунікативної культури; будучи їх підсистемою, комунікативна культура зберігає свою цілісність і відносну автономність [Капушева].

У сфері вищої освіти теоретична постановка питання формування комунікативної культури та результати їх практичного втілення і впровадження навчальних курсів, які вивчають комунікативну культуру, показали необхідність того, що комунікативна культура $є$ складовою частиною базової культури особистості.

Досліджуючи особливості формування комунікативної культури студентів у позааудиторній діяльності, О. Гаврилюк розглядає комунікативну культуру як «складне динамічне особистісне утворення, що відображає соціально зумовлений рівень розвитку особистості, ії готовність до комунікативної діяльності, систему поглядів і дій, які забезпечують задоволення потреб самореалізації і спосіб досягнення цілей у спілкуванні, плідну доброзичливу взаємодію людей у різних сферах життєдіяльності» [Гаврилюк : 118].

Результати. Для освітньої сфери характерна діалогічна комунікативна культура, яка залежить від діалогічної компетентності членів колективу. Діалогічна комунікативна культура характеризується готовністю членів колективу до узгодження один із одним особистісних цінностей і смислів, здатністю до адекватного, позитивного, ефективного ділового і міжособистісного спілкування. Ця культура передба- чає таке ділове та міжособистісне спілкування, яке сприяє творчому розвитку особистості, виключаючи будь-які способи насилля над нею.

Досліджуючи значення комунікативної культури у професійному розвитку здобувачів вищої освіти, ми погоджуємося $з$ думкою науковця М. Рудь, який комунікативну культуру розкриває як здатність до узгодження i співвіднесення своїх дій із іншими, прийняття i сприйнятливості іншого, до підбору і пред'явленню аргументів, висунення альтернативних пояснень, обговорення проблеми, розуміння і поваги думок інших і на основі цього - до регулювання відносин задля створення спільноти, що навчається для досягнення єдиної мети діяльності; потреба в іншому, у розширенні кордонів комунікацій, зіставленні різних поглядів; уміння стати на позицію учнів; готовність до гнучкої тактичної взаємодії із іншим, до рефлексивної діяльності, до проєктування комунікативних умінь і застосування їх у новій ситуації [Рудь : 118].

Розглядаючи комунікативну культуру як специфічний спосіб організації спілкування, С. Знаменська відзначає, що вона характеризується наявністю комунікативного ідеалу, системою комунікативних норм і правил, поважним ставленням до співбесідника, знанням його індивідуальних особливостей, власних комунікативних здібностей та умінням володіти комунікативною ситуацією. «Комунікативна культура $є$ системою внутрішніх ресурсів, потрібних для побудови ефективної комунікації у певному колі ситуацій міжособистісної взаємодії» [Знаменська : 84].

У свою чергу О. Кравченко розуміє комунікативну культуру особистості як «комплекс сформованих знань і вмінь у царині міжособистісного спілкування, що проявляються у ставленні до людей, в умінні контролювати й регулювати свою мовленнєву поведінку, правильно аргументувати свою позицію, продуктивно співпрацювати за допомогою вербальних та невербальних засобів і способів спілкування» [Кравченко : 49].

Отже, проаналізувавши сутність поняття «комунікативна культура», варто відзначити, що це поняття містить:

- орієнтацію на визнання позитивних якостей, сильних сторін, значущості іншого; 
- уміння давати позитивний зворотний зв'язок іншому;

- уміння мотивувати інших на діяльність задля досягнення цілей;

- конкретні комунікативні вміння: вітати, спілкуватися, задавати питання, відповідати, активно слухати, оцінювати, просити, підтримувати, відмовляти;

- повага до самого себе, знання власних сильних сторін і вміння використовувати їх у своїй діяльності;

- здатність контролювати свій емоційний стан;

- мовну культуру, під якою розуміють володіння літературною мовою, яка містить лексичні, стилістичні, орфоепічні та інші норми.

Із позицій діяльнісного підходу М. Шовкун розглядає комунікативну культуру фахівця як атрибут діяльності та іiі результатів у взаємодії між суб'єктами. У цьому контексті її структуру утворюють такі компоненти:

1) світоглядний (система поглядів і знань майбутнього фахівця, етичних та естетичних норм обраної професії), спрямований на досягнення професійного результату через високий духовний потенціал;

2) визнання абсолютної цінності особистості, дотримання у повсякденній міжособистісній діяльності прийнятих етичних норм;

3) мотиваційний (мотиви комунікативної поведінки, комунікативні установки, професійна спрямованість), в якому домінує потреба розуміння та усвідомлення особливостей майбутньої професії;

4) власне комунікативний (комунікативні вміння і навички, професійна спрямованість мовлення), скерований на усвідомлення спілкування як засіб досягнення мети у міжособистісних стосунках;

5) розвиток i саморозвиток особистості, стимул для формування важливих особистісних і професійних якостей;

6) емоційно-вольовий

(тактовність, витримка, толерантність), який сприяє добору доцільних емоційно виправданих засобів мовного та немовного впливу;

7) конструктивний - здатність обирати оптимальний стиль спілкування і взаємодії, комунікативної поведінки, адекватного сприйняття особистістю себе як фахівця [Шовкун].
Нині комунікативна культура $є$ важливою умовою професійного розвитку та може розглядатися як система особистісних потенціалів, потрібних для вибудовування шляхів ефективного професійного розвитку. Компетентність у спілкуванні містить досвід історично і культурно зумовленого спілкування, побудова якого часто має варіативні загальнолюдські характеристики, що відображають етнічні особливості. Отже, для успішного професійного розвитку слід розглядати комунікативну культуру як основу, що передбачає знання менталітету, особливостей традицій, звичаїв та етичних правил різних спільнот. Під час багатопланового спілкування забезпечується єдність взаєморозуміння та узгодженість вчинків, намірів, поведінки, відображаються якості людини як суб'єкта багатонаціональної культури.

Головним завданням формування комунікативної культури майбутніх фахівців є спрямованість діяльності на забезпечення якості освіти випускників. Якість професійної освіти студентів характеризується не тільки обсягом знань і складом навичок, але й готовністю до певних видів діяльності, до встановлення взаємовідносин із іншими людьми, що є необхідним у сучасному суспільстві.

Існує кілька таких підходів у системі формування комунікативної культури:

- культурологічний підхід (зумовлений об'єктивним зв'язком людини 3 культурою як із системою цінностей);

- діяльнісний підхід (процес спілкування органічно включається в усі види діяльності та взаємодії людей);

- цілісний підхід (потрібно здійснювати і соціальну, і предметну підготовку);

- особистісний підхід (механізми, зміст, характер спілкування залежать від його учасників, від їх особистісного розвитку) [Chernukha et al].

Виходячи 3 того, що комунікативна культура характеризує якість комунікативної діяльності, ми приділяємо особливу увагу цьому процесу у системі професійного розвитку майбутнього фахівця. Підготовка до професійної діяльності передбачає формування структурних компонентів комунікативної культури в різних аспектах: мотиваційно-ціннісному, змістовному і практичному. Відтак, комунікативна 
діяльність постає як умова та засіб формування комунікативної культури. Під час професійної підготовки студентів культивується ціннісне ставлення до спілкування, висуваються вимоги, яким повинна відповідати комунікативна діяльність майбутнього фахівця.

На підставі теоретичного аналізу ми визначили, що розвиток комунікативної культури здобувачів вищої освіти передбачає:

- вдосконалення особистісних і професійних якостей майбутніх фахівців;

- формування вмінь конструктивно спілкуватися на всіх етапах професійної діяльності, встановлювати і підтримувати контакти 3 іншими людьми з урахуванням вікових, статусних та соціально-культурних характеристик;

- адекватне та ефективне використання невербального і вербального каналів спілкування у професійній діяльності;

- подолання комунікативних бар'єрів;

- володіння способами саморегуляції та самоконтролю під час міжособистісної комунікативної взаємодії, вироблення навичок професійного ведення діалогу тощо.

Висновки. Комунікативна культура як соціально-психологічне утворення у структурі особистості дозволяє особистості розвиватись у гармонії із загальнолюдською культурою і набувати соціальної стійкості. Будучи одним iз пріоритетних завдань професійної освіти, комунікативну культуру розглядають як найважливіший складник гуманітарної освіти, як спеціальний об'єкт моделювання педагогічних систем в єдності їх структурних і функціональних компонентів. Комунікативна культура, яку ми розглядаємо в межах педагогічного процесу, у поєднанні цільового, змістовного і процесуального аспектів освітньої діяльності, постає як сукупність ціннісних структур у вигляді емоційної або моральної культури, культури мислення і культури мови, що сприяе професійному розвитку особистості.

Комунікативна культура є сукупністю норм, способів і форм взаємодії та містить кращі зразки і цінності поведінки. Професійна підготовка має бути спрямована на досягнення здобувачами вищої освіти професійної компетентності, під якою розуміють оволодіння фахівцем усією сукупністю культурних зразків, одним із яких виступає комунікативна культура. Комунікативну культуру слід розглядати як частину загальної культури особистості, один із базових компонентів, який забезпечує готовність до життєвого самовизначення, $\epsilon$ умовою досягнення гармонії із собою і навколишньою дійсністю та засобом створення внутрішнього світу особистості, багатства його змісту, що відображає життєві ідеали і спрямованість на культуру іiі життєвого самовизначення. Розуміння комунікативної культури як засобу та умови формування особистості майбутнього фахівця грунтується на пізнанні іï адаптивних можливостей, які допомагають людині діяти відповідно до культурних стандартів значущого для неї оточення.

\section{ЛІТЕРАТУРА}

1. Гаврилюк О. Формування комунікативної культури майбутніх учителів у вищому навчальному закладі. Педагогіка вищої та середньої школи: Зб. наук. пращь. 2005. Вип. 11. С. 116-121.

2. Знаменская С. Педагогические условия формирования коммуникативной культуры студентов в процессе профессиональной подготовки в вузе : Дис. ... канд. пед. наук. Ставрополь, 2004. 214 с.

3. Каппушева М. Формирования коммуникативной культуры студентов в условиях информатизации образовательного процесса вуза: Дис. ... канд. пед. наук. Ставрополь, 2004. 175 с.

4. Кравченко А. И. Культурология: учебник. Москва : ТК Велби, Изд-во Проспект, 2020. 288 с.

5. Митрова И. Теоретические аспекты формирования коммуникативной культуры. Вестник АГУ. 2005. № 1 (16). С. 148-149.

6. Рудь М. Формирование коммуникативной культуры будущего учителя начальных классов в педагогическом колледже: Дис. ... канд. пед. наук. Ростов-на-Дону, 1999. 132 с.

7. Шовкун М. П. Складові комунікативної культури студентів. Педагогіка, психологія та медико-біологічні проблеми фізичного виховання і спорту. 2003. № 8. С. 45-50.

8. Chernukha N., Brovko E., Zagorodnya A., Ternopolskay V., Ali Shaheid Anad (2020) Diagnostics and peculiarities of students' corporate culture in university educational environment. Utopía y praxis latinoamericana. URL: https:// https://doi.org/10.5281/zenodo.3984210 (accessed: 27 August 2021).

\section{REFERENCES}

1. Havryliuk O. (2005) Formuvannia komunikatyvnoi kul'tury majbutnikh uchyteliv u vyschomu navchal'nomu zakladi. [Formation of communicative culture of future teachers in higher education]. Higher and secondary school pedagogy, vol. 11. pp. 116-121. (in Ukrainian). 
2. Znamenskaja S. (2004) Pedagogicheskie uslovija formirovanija kommunikativnoj kul'tury studentov v processe professional'noj podgotovki $v$ vuze [Pedagogical conditions for the formation of the communicative culture of students in the process of professional training in a higher educational institution] (PhD Thesis), Stavropol: Stavropol State University (in Russian).

3. Kappusheva M. (2004) Formirovanija kommunikativnoj kul'tury studentov $v$ uslovijah informatizacii obrazovatel'nogo processa vuza [Formation of the communicative culture of students in the context of informatization of the educational process of a higher educational institution] (PhD Thesis), Stavropol: North Caucasus State Technical University. (in Russian).

4. Kravchenko A. (2020) Kul'turologija [Culturology]. Moscow: Prospekt. (in Russian).

5. Mitrova I. (2005) Teoreticheskie aspekty formirovanija kommunikativnoj kul'tury [Theoretical aspects of the formation of a communicative culture] Vestnik $A G U$. No. 1 (16). pp. 148-149 (in Russian).

6. Rud'M.(1999)Formirovaniekommunikativnoj kul'turybudushhegouchiteljanachal'nyhklassovvpedagogicheskom kolledzhe [Formation of the communicative culture of the future primary school teacher in the pedagogical college] : (PhD Thesis). - Rostov-on-Don: Rostov State Pedagogical University (in Russian).

7. Shovkun M. (2003) Skladovi komunikativnoï kul'turi studentiv [Components of students' communicative culture]. Pedahohika, psykholohiya ta medyko-biolohichni problemy fizychnoho vykhovannya i sportu, no.8, pp. 45-50 (in Ukrainian).

8. Chernukha N., Brovko E., Zagorodnya A., Ternopolskay V., Ali Shaheid Anad (2020) Diagnostics and peculiarities of students' corporate culture in university educational environment. Utopía y praxis latinoamericana. Retrieved from: https:// https://doi.org/10.5281/zenodo.3984210 (accessed: 27 August 2021) (in English).

\section{YANG MENGYI}

Postgraduate Student at the Department of Social Pedagogy,

National Pedagogical Dragomanova University,

Kiev, Ukraine - China

E-mail: sivkivskay@gmail.com,714862806@qq.com

https://orcid.org/0000-0001-8163-5531

\section{THE IMPORTANCE OF COMMUNICATIVE CULTURE OF STUDENTS OF HIGHER EDUCATIONAL IN THEIR PROFESSIONAL DEVELOPMENT}

The article analyzes the problem of communicative culture as a socio-psychological component in the structure of personality, which allows individuals to develop in harmony with human culture and acquire social stability and determines that it is based on moral values, knowledge of types and forms of communication, qualities necessary for full communication. The aim of the study was to theoretically substantiate the communicative culture of higher education students in their professional development during their studies. Theoretical analysis of domestic and foreign scientific and methodological literature is given. Different author's views on the concept of "communicative culture" are analyzed. The components of communicative culture are generalized: emotional culture or culture of feelings, culture of thinking and language culture. It is established that communicative culture presupposes the presence of a communicative ideal, a system of communicative norms and rules, one's own communicative abilities and skills. It is determined that the communicative culture ensures the readiness of the individual for vital and professional self-determination and is a condition for successful professional development of the future specialist. The professional components of the communicative culture of the specialist are revealed. It is proved that the means and condition of communicative culture is communicative activity, so in the process of professional training of higher education students there are requirements that must be met by the communicative activity of the future specialist. For a specialist as a subject of professional activity, the way of cognition and transformation of the world is professional culture, and the way of transformation of oneself is communicative culture. In this case, the communicative culture is a set of special communicative knowledge, skills and abilities by which a person prevents psychological difficulties and predicts the effectiveness of interpersonal and business professional interaction.

Key words: communication, communicative activity, communicative culture, higher education seeker. 